\title{
Bio efficacy of New Insecticide Molecules Chlorantraniliprole 35\% WG against Sugarcane Early Shoot Borer Chilo infuscatellus (Snellen) and Internode Borer Chilo sacchariphagus indicus (Kapur)
}

\author{
N.M. Sunilkumar ${ }^{1}$, Arunkumar Hosamani ${ }^{2}$, M. Shobharani ${ }^{3}$ and R.L. Jadhav ${ }^{4}$ \\ ${ }^{1}$ Agriculture Entomology, ${ }^{4}$ Agronomy, ICAR- Krishi Vigyan Kendra, \\ Bidar-585402, Karnataka, India \\ ${ }^{2}$ Biological Unit, UAS, Raichur-584101 Karnataka, India \\ ${ }^{3}$ Agricultural Research Station, Bidar-585402, Karnataka, India \\ *Corresponding author
}

\section{A B S T R A C T}

Keywords

Bioefficacy,

Chlorantraniliprole

$35 \% \mathrm{WG}$,

Sugarcane early

shoot borer, Chilo

Infuscatellus,

Internode borer

Chilo

sacchariphagus

indicus

Article Info

Accepted:

30 November 2018

Available Online:

10 December 2018
An experiment was conducted on Bioefficacy of Chlorantraniliprole $35 \%$ WG against early shoot borer and internode borer of Sugarcane at Agricultural Research Station, Bidar, University of Agricultural Sciences, Raichur during 2014-15 and 2015-16. The varied dosages of Chlorantraniliprole $35 \% \mathrm{WG}$ in comparison with different insecticides were tested along with untreated check using randomized block design with three replications. Significant differences were noticed among the treatments. Among the different insecticides evaluated. Drenching the sets immediately after planting in furrow with Chloranthriniliprole 35\%WG @ 88 gai/ha and Chloranthriniliprole 35\%WG @ 75 gai/ha, were proved superior by recording lowest average per cent dead hearts by early shoot borer and average per cent Internode borer damage whereas untreated control recorded highest pest infestation and also recorded the B:C ratio of 3.26 , 3.18 and 2.16 respectively.

\section{Introduction}

Sugarcane (Saccharum officinarum L.) is an important commercial cash crop of India. It is being cultivated in more than seventy countries. India ranks first in the world in the area under sugarcane cultivation and ranks fifth in the world in terms of sugar production. In India sugarcane occupies an area of $5.01 \mathrm{~m}$ ha and produces $338.96 \mathrm{~m}$ tonnes of cane with an average productivity of 66.99 tones $\mathrm{ha}^{-1}$ (Anonymous, 2015). Sugarcane crop is currently facing severe crises in the country and both industry and the farming community are striving for its sustainable existence and growth. 
The major challenges faced by the crop are less average per area production, low sugar recovery and higher cost of production. There are several reasons for low yields in viz., early shoot borer Chilo infuscatellus and the internode borer Chilo sacchariphagus indicus (Kapur). The early shoot borer damages sugarcane crop mainly at growth and development phase. The young larvae bore down the spindles as also upwards destroying the growing apical meristem. Consequently the cut of spindle dries up and develops into a conspicuous "dead heart" that can be pulled out easily and emit a unpleasant smell and results in tiller gap due to killing of mother shoots.

The production and productivity of the sugarcane are affected by many factors viz., soil type, selections of variety, fertilizer management, irrigation management and damage caused by pests. Sugarcane is attacked by several insects' pests. However, 15 pests are reported to cause considerable loss in yield. The damage by Chilo infuscatellus ranges from 30-75 per cent in early stages of the crop (May-June) in subtropical India (Krishnamurthy Rao, 1954). Infestation and subsequent damage by inter node borer Chilo sacchariphagus indicus is matter of concern. Among the pest, Gupta (1993) reported more than 45 per cent of yield losses in sugarcane are due to infestation by borer pests alone

Keeping in view the economics, importance of the pest and the crop, field studies were carried out to determine the chemical control measures for sugarcane stem borer at Agricultural Research Station, Bidar, Karnataka.

\section{Materials and Methods}

A field experiment was conducted for two successive years during 2014-15 and 2015-16 at Agricultural Research Station, Bidar to assess the chemical control of sugarcane early shoot borer (Chilo infuscatellus Snellen) and inter node borer Chilo sacchariphagus indicus.

The experiment was laid out in Randomized block design with ten treatments replicated thrice. The Sugarcane Variety Co 94012 was sown at $\mathrm{cm} 90 \times 20 \mathrm{~cm}$ spacing with plot size of 7.5 x $4 \mathrm{mts}$. and all the recommended package of practices were followed to raise the crop, except plants protection measures. The drenching the sets immediately after planting in furrow with and spray of insecticides was done at initiation of pest infestation in all the experimental plots. The spraying insecticides were carried out during morning hours by hand operated knapsack sprayer.

Seven trials were initiated with various insecticides. viz., three varied dosages of Chlorantraniliprole $35 \% \mathrm{WG}$, spraying with Chlorantraniliprole 18.5 SC @ 75 gai, Chlorpyriphos 20 EC @ 300 gai and Fipronil 5 SC @ 75g ai/ ha were tried and compared with an untreated control.

Initially in first three treatments sugarcane sets were drenched with Chlorantraniliprole $35 \% \mathrm{WG}$ immediately after planting in furrow with three varied dosages. In the remaining treatments spraying of insecticides was done at initiation of pest in all the experimental plots.

Observations on the incidence of ESB, was recorded on 30, 45, 60, and $90 \mathrm{DAP}$ and per cent shoot borer incidence was worked out. The incidence of sugarcane internode borer was observed and evaluated at the time of harvest in 25 randomly selected canes in each plot by counting number of internodes and damaged internodes per cane.

Pest incidence and pest intensity were calculated using following formulae: 
1. Per cent inter node shoot borer incidence: Affected canes X 100 Total canes

2. Per cent inter node borer intensity: Affected nodes X 100

Total nodes

3. Per cent inter node borer infestation: Percent incidence X Per cent intensity 100

The experiments were subjected to statistical analysis following the method of Panse and Sukhatme (1985). The net benefit was obtained by subtracting the total cost of the treatment from the gross income of the treatments. Cost benefit ratio were calculated through gross income divided by total cost. Greater the C: B ratio indicates the efficiency of the treatment.

\section{Results and Discussion}

The results on the per cent cumulative incidence of early shoot borer Chilo infuscatellus Snellen and inter node borer Chilo sacchariphagus indicus at 30, 45,60 and 90 days after planting are presented in Table1 and 2.

Among all the treatments Chlorantraniliprole 35WG @ 88 gai per ha at 30,45,60 and 90 days after drenching (DAD) had recorded respectively $0.22,1.71,2.03$ and 2.21 average per cent dead hearts by early shoot borer which was significantly superior compared to all other treatments and was at par with the treatment Chlorantraniliprole 35WG @75 gai per ha. These two treatments were followed by Chlorantraniliprole 18.5SC @ 75gai per ha and Chlorantraniliprole 35\%WG @62 gai/ha. The treatment Fipronil 5SC @ 75gai/ha at 30, 45, 60 and 90 days after spraying (DAS) had recorded respectively $19.37,5.74,5.58$ and 9.10 average per cent dead hearts by early shoot borer which is followed by Chlorpyriphos 20 EC (Spray)@ 300gai/ha and it recorded 17.94, 12.86, 17.85 and 13.74 average per cent dead hearts respectively on 30,45,60 and 90 days after spraying (DAS). The average percent dead hearts were significantly low in all the insecticidal treatments as compare to untreated control which recorded 18.23, 21.92, 17.15 and 15.81 per cent dead hearts on 30,45,60 and 90 Days during 2014-15 and the same trend was observed during 2015-16 (Table 1 and 2).

It was observed that soil drenching with Chlorantraniliprole 35WG @ 88 gai/ ha has recorded significantly lower average per cent Internode borer infestation at harvest $(0.92$ and 0.82 during 2014-15 and 2015-16 respectively) which was at par with Chlorantraniliprole 35WG @ 75 gai/ ha (0.82 and 1.24 during 2014-15 and 2015-16) fallowed by Chlorantraniliprole $18.5 \% \mathrm{SC}$ (Drenching)1.71 and 0.53 per cent average per cent Internode borer infestation with Chlorantraniliprole $35 \% \mathrm{WG}$ drenching.The highest average per cent Internode borer infestation was recorded in untreated check i.e., 6.25 and 5.22 during 2014-15 and 201516 (Table 1 and 2). These findings are in line with the results of Pandey (2014), Anonymous (2015) and Padmasri et al., (2014) who reported that Chlorantraniliprole $0.4 \mathrm{G}$ and Chlorantraniliprole 18.5 SC are the most effective insecticide against ESB.

The highest cane yield was recorded in Chlorantraniliprole 35WG @ 88 gai per ha (94.19 and 102.25 t/ha during 2014-15 and 2015-16) which was at par with Chlorantraniliprole 35WG @ 75 gai per ha (89.83 and 98.13 t/ha during 2014-15 and 2015-16) which was closely followed by Chlorantraniliprole 18.5 SC @ 75gai/ha (85.73 and 94.72 t/ha), Chlorantraniliprole 35WG @ 62gai/ha (76.91 and 85.02 t/ha during 2014-15 and 2015-16), Fipronil 5SC@ 75gai/ha (72.61 and 86.72 t/ha during 201415 and 2015-16) and Chlorpyriphos 20EC@ 300 gai/ha (57.04 and 65.34 t/ha during 201415 and 2015-16). 
Table.1 Bio efficacy of Chlorantraniliprole 35\% WG against early shoot borer and internode borer of Sugarcane-2014

\begin{tabular}{|c|c|c|c|c|c|c|c|c|c|c|c|c|c|}
\hline \multirow{3}{*}{$\begin{array}{c}\text { Treatment: } \\
\text { T1 }\end{array}$} & \multirow{3}{*}{ Treatments } & \multirow{3}{*}{$\begin{array}{l}\text { Dosage } \\
\text { g ai/ha } \\
62\end{array}$} & \multicolumn{8}{|c|}{ Average per cent dead hearts by early shoot borer } & \multirow{2}{*}{\multicolumn{2}{|c|}{$\begin{array}{c}\text { Average \% } \\
\text { Internode borer } \\
\text { at harvest }\end{array}$}} & \multirow{3}{*}{$\begin{array}{c}\text { Yield } \\
\text { tons/ha } \\
76.71\end{array}$} \\
\hline & & & \multicolumn{2}{|c|}{30 DAS } & \multicolumn{2}{|c|}{45 DAS } & \multicolumn{2}{|c|}{60 DAS } & \multicolumn{2}{|c|}{90 DAS } & & & \\
\hline & & & 1.65 & $(7.31)$ & 3.51 & $(10.79)$ & 4.51 & $(12.07)$ & 5.78 & $(13.75)$ & 3.33 & $(10.46)$ & \\
\hline $\mathbf{T 2}$ & Chlorantraniliprole 35\%WG (Drenching) & 75 & 0.42 & $(3.70)$ & 2.16 & $(8.44)$ & 2.43 & $(8.84)$ & 3.05 & $(9.95)$ & 1.88 & $(7.87)$ & 89.83 \\
\hline T3 & Chlorantraniliprole 35\%WG (Drenching) & 88 & 0.22 & $(2.65)$ & 1.71 & $(7.39)$ & 2.03 & $(8.16)$ & 2.21 & $(8.53)$ & 0.92 & $(5.50)$ & 94.19 \\
\hline T4 & Chlorantraniliprole $18.5 \%$ SC (Drenching) & 75 & 0.43 & $(3.75)$ & 1.47 & $(6.94)$ & 2.62 & $(9.27)$ & 4.42 & $(12.02)$ & 1.71 & $(7.50)$ & 85.73 \\
\hline T5 & Chlorpyriphos 20 EC (Spray) & 300 & 17.94 & $(24.98)$ & 12.86 & $(20.99)$ & 17.85 & $(24.97)$ & 13.74 & $(21.72)$ & 4.28 & $(11.87)$ & 57.04 \\
\hline T6 & Fipronil 5 SC & 75 & 16.51 & $(23.68)$ & 5.74 & $(13.59)$ & 5.58 & $(13.62)$ & 9.10 & $(17.40)$ & 2.31 & $(8.71)$ & 72.61 \\
\hline \multirow[t]{4}{*}{$\mathrm{T7}$} & Untreated Check & - & 19.61 & $(26.23)$ & 21.92 & $(27.88)$ & 17.15 & $(24.42)$ & 15.81 & $(23.41)$ & 6.25 & $(14.46)$ & 53.16 \\
\hline & & SEM & \multicolumn{2}{|c|}{1.20} & \multicolumn{2}{|c|}{1.07} & \multicolumn{2}{|c|}{0.74} & \multicolumn{2}{|c|}{1.19} & & 0.58 & 5.35 \\
\hline & & CD@5\% & \multicolumn{2}{|c|}{3.71} & \multirow{2}{*}{\multicolumn{2}{|c|}{3.31}} & \multicolumn{2}{|c|}{2.28} & \multirow{2}{*}{\multicolumn{2}{|c|}{3.68}} & \multicolumn{2}{|r|}{1.77} & 16.48 \\
\hline & & $\mathrm{CV}$ & \multicolumn{2}{|c|}{15.59} & & & \multicolumn{2}{|c|}{8.97} & & & & 10.51 & 12.25 \\
\hline
\end{tabular}

DAS: Day after spray $\quad *$ Figures in parentheses are square root transformed values

Table.2 Bioefficacy of chlorantraniliprole 35\% WG against early shoot borer and internode borer of Sugarcane-2015

\begin{tabular}{|c|c|c|c|c|c|c|c|c|c|c|c|c|c|}
\hline \multirow{3}{*}{$\begin{array}{c}\text { Treatments } \\
\text { T1 }\end{array}$} & \multirow{3}{*}{ Treatments } & \multirow{3}{*}{$\begin{array}{l}\text { Dosage } \\
\text { g ai/ha } \\
62\end{array}$} & \multicolumn{8}{|c|}{ Average per cent dead hearts by early shoot borer } & \multirow{2}{*}{\multicolumn{2}{|c|}{$\begin{array}{c}\text { Average \% } \\
\text { Internode borer } \\
\text { at harvest }\end{array}$}} & \multirow{3}{*}{$\begin{array}{l}\text { Yield } \\
\text { tons/ha } \\
85.02\end{array}$} \\
\hline & & & \multicolumn{2}{|c|}{30 DAS } & \multicolumn{2}{|c|}{45 DAS } & \multicolumn{2}{|c|}{60 DAS } & \multicolumn{2}{|c|}{90 DAS } & & & \\
\hline & & & 2.9 & $(9.77)$ & 3.56 & $(10.71)$ & 5.12 & $(13.03)$ & 7.22 & $(15.51)$ & 2.56 & $(8.87)$ & \\
\hline T2 & Chlorantraniliprole 35\%WG (Drenching) & 75 & 0.96 & $(5.44)$ & 1.90 & $(7.85)$ & 3.54 & $(10.60)$ & 3.91 & $(11.39)$ & 1.24 & $(6.07)$ & 98.13 \\
\hline T3 & Chlorantraniliprole 35\%WG (Drenching) & 88 & 0.52 & $(4.09)$ & 1.20 & $(6.09)$ & 2.46 & $(9.02)$ & 3.66 & $(11.01)$ & 0.82 & $(5.19)$ & 102.25 \\
\hline$\overline{T 4}$ & Chlorantraniliprole $18.5 \%$ SC (Drenching) & 75 & 1.24 & $(6.35)$ & 1.80 & $(7.66)$ & 3.90 & $(10.85)$ & 4.91 & $(12.79)$ & 0.53 & $(4.14)$ & 94.72 \\
\hline T5 & Chlorpyriphos 20 EC (Spray) & 300 & 17.25 & $(24.51)$ & 11.25 & $(19.55)$ & 15.80 & $(24.40)$ & 14.75 & $(22.54)$ & 3.12 & $(10.17)$ & 65.34 \\
\hline T6 & Fipronil 5 SC & 75 & 16.12 & $(23.04)$ & 4.36 & $(11.86)$ & 7.82 & $(16.21)$ & 15.28 & $(22.80)$ & 1.95 & (7.91) & 86.72 \\
\hline \multirow[t]{4}{*}{ T7 } & Untreated Check & - & 22.50 & $(28.22)$ & 19.65 & $(26.25)$ & 21.35 & $(27.45)$ & 22.14 & (28.01) & 5.22 & (13.20) & 61.36 \\
\hline & & SEM & \multicolumn{2}{|l|}{1.01} & \multicolumn{2}{|l|}{1.20} & \multicolumn{2}{|l|}{1.52} & \multicolumn{2}{|l|}{1.29} & \multicolumn{2}{|l|}{0.69} & 5.40 \\
\hline & & CD@5\% & \multicolumn{2}{|l|}{3.11} & \multicolumn{2}{|l|}{3.71} & \multicolumn{2}{|l|}{4.67} & \multicolumn{2}{|l|}{3.97} & \multicolumn{2}{|l|}{2.11} & 16.63 \\
\hline & & $\mathrm{CV}$ & \multicolumn{2}{|l|}{12.00} & \multicolumn{2}{|l|}{16.21} & \multicolumn{2}{|l|}{16.10} & \multicolumn{2}{|l|}{12.58} & \multicolumn{2}{|c|}{14.97} & 11.02 \\
\hline
\end{tabular}

DAS: Day after spray * Figures in parentheses are square root transformed values 


\section{Int.J.Curr.Microbiol.App.Sci (2018) 7(12): 3680-3685}

Table.3 Cost economics of sugarcane borers management

\begin{tabular}{|c|c|c|c|c|c|c|c|c|c|c|}
\hline \multirow[t]{2}{*}{ Treatments } & \multirow{2}{*}{\multicolumn{2}{|c|}{ Treatments }} & \multirow{2}{*}{$\begin{array}{l}\text { Dosage } \\
\text { g ai/ha }\end{array}$} & \multirow{2}{*}{$\begin{array}{c}\text { Average } \\
\text { yield } \\
\text { kg/ha }\end{array}$} & \multirow{2}{*}{$\begin{array}{l}\text { Gross } \\
\text { returns }\end{array}$} & \multicolumn{2}{|c|}{ Cost Involved (Rs.) } & \multirow{2}{*}{$\begin{array}{l}\text { Total Cost } \\
\text { (Rs.) }\end{array}$} & \multirow{2}{*}{$\begin{array}{l}\text { Net Profit } \\
\text { (Rs.) }\end{array}$} & \multirow{2}{*}{$\begin{array}{l}\text { Benefit : } \\
\text { cost } \\
\text { ratio }\end{array}$} \\
\hline & & & & & & $\begin{array}{l}\text { Management } \\
\text { Cost }\end{array}$ & $\begin{array}{l}\text { Other } \\
\text { Expenditure }\end{array}$ & & & \\
\hline T1 & $\begin{array}{l}\text { Chlorantraniliprole } \\
\text { (Drenching) }\end{array}$ & $35 \% \mathrm{WG}$ & 62 & 80.87 & 137470.50 & 4455 & 45000 & 49455 & 88015.50 & 2.78 \\
\hline $\mathbf{T 2}$ & $\begin{array}{l}\text { Chlorantraniliprole } \\
\text { (Drenching) }\end{array}$ & $35 \% \mathrm{WG}$ & 75 & 93.98 & 159766.00 & 5205 & 45000 & 50205 & 109561.00 & 3.18 \\
\hline T3 & $\begin{array}{l}\text { Chlorantraniliprole } \\
\text { (Drenching) }\end{array}$ & $35 \% \mathrm{WG}$ & 88 & 98.22 & 166974.00 & 6195 & 45000 & 51195 & 115779.00 & 3.26 \\
\hline T4 & $\begin{array}{l}\text { Chlorantraniliprole } \\
\text { (Drenching) }\end{array}$ & $18.5 \% \mathrm{SC}$ & 75 & 90.23 & 153382.50 & 14145 & 45000 & 59145 & 94237.50 & 2.59 \\
\hline T5 & \multicolumn{2}{|c|}{ Chlorpyriphos 20 EC (Spray) } & 300 & 61.19 & 104023.00 & 412 & 45000 & 45412 & 58611.00 & 2.29 \\
\hline T6 & \multicolumn{2}{|l|}{ Fipronil 5 SC } & 75 & 79.67 & 135430.50 & 1800 & 45000 & 46800 & 88630.50 & 2.89 \\
\hline T7 & \multicolumn{2}{|l|}{ Untreated Check } & - & 57.26 & 97342.00 & & 45000 & 45000 & 52342.00 & 2.16 \\
\hline
\end{tabular}

Sugarcane Price Rs $1700 / \mathrm{t}$ 
Lowest yield (53.16 t/ha and $61.36 \mathrm{t} / \mathrm{ha}$ during 2014-15 and 2015-16) was recorded in untreated check (Table 1). These results are in accordance with Pandey (2014) who reported higher cane yield in Chlorantraniliprole 0.4G; Padmasri et al., (2014) reported higher cane yield in Chlorantraniliprole 18.5 SC.

By working out the benefit : cost ratio, it was found that Chlorantraniliprole 35WG @88 gai per ha registered highest cost: benefit ratio (1: 3.26) followed by Chlorantraniliprole 35WG @ 75 gai per ha (1: 3.18), Fipronil 5 SC@75gai/ha(1: 2.89), Chlorantraniliprole 35WG @62 gai per ha (1: 2.78), Chlorantraniliprole 18.5\%SC @ 75 gai per ha (1: 2.59), Chlorpyriphos 20 EC @300 gai per ha (1: 2.29) and the untreated control recorded the lowest benefit : cost ratio (1: 2.16) (Table 3). Padmasri et al., (2014) who reported high B:C ratio with Flubendiamide 39.35SC and Spinosad 45SC. Chlorantraniliprole 18.5 SC has the highest cost than all other test insecticides but it gave the maximum per cent reduction of early shoot borer.

In conclusion, studies on bioefficacy of new insecticide molecules Chlorantraniliprole 35\% WG against Sugarcane early shoot borer Chilo infuscatellus and the internode borer Chilo sacchariphagus indicus revealed that the drenching with Chlorantraniliprole 35WG @ 88gai/ha recorded lowest cumulative incidence and highest per cent reduction over the control with highest canes yield and have also recorded better cost benefit ratio.

\section{References}

Anonymous, (2015). Zonal Research and Extension Programme Workshop. University of Agriculture Sciences, Bangalore.

Gupta, S.C., Yazdani, S.S., Hameed, S.F. and Agarwal, M.L. (1993). Losses in sugarcane by different broods of top borer, Scirpophaga excerptalis Walker in northern Bihar. J. Insect Sci., 6(1): 125-127.

Padmasri, A., Vidyasagar, G.E. and Bharathi, V. (2014). Evaluation of new molecules for management of stem borer on sugarcane. J. Agric. Vet. Sci., 7(6): 40 42.

Pandey, S.K. (2014). Comparative efficacy of some insecticides on early shoot borer (Chilo infuscatellus Snellen) incidence in sugarcane under subtropical India. VEGETOS, 27(1): 146-148.

Panse, V.G and Sukhatme, P.K, 1985. Statistical methods for Agricultural workers, ICAR, New Delhi.

\section{How to cite this article:}

Sunilkumar, N.M., Arunkumar Hosamani, M. Shobharani and Jadhav, R.L. 2018. Bio efficacy of New Insecticide Molecules Chlorantraniliprole 35\% WG against Sugarcane Early Shoot Borer Chilo infuscatellus (Snellen) and Internode Borer Chilo sacchariphagus indicus (Kapur). Int.J.Curr.Microbiol.App.Sci. 7(12): 3680-3685. doi: https://doi.org/10.20546/ijcmas.2018.712.416 